\title{
OPEM
}

www.opem.org

Oriental Pharmacy and Experimental Medicine 2009 9(3), 252-258

DOI 10.3742/OPEM.2009.9.3.252

\section{Phytochemical and pharmacological evaluation of the flowers of Sarcostemma brevistigma Wight}

\author{
KG Lalitha ${ }^{1}$ and MG Sethuraman ${ }^{2, *}$ \\ ${ }^{1}$ Department of Pharmaceutical Chemistry, Ultra College of Pharmacy, Madurai-625 020, Tamil Nadu, India; \\ ${ }^{2}$ Department of Chemistry, Gandhigram Rural Institute, Gandhigram - 624 302, Tamil Nadu, India
}

Received for publication July 05, 2007; accepted February 23, 2009

\begin{abstract}
SUMMARY
Shade-dried flowers of Sarcostemma brevistigma Wight Syn (SBF) belonging to Asclepiadaceae yielded a rare flavonol glycoside viz., Quercetin 5a prenyl, 3-O-glucosyl, 7-O-(4c-p-coumaroyl) neohesperidoside which were characterized based on chemical and spectral (including 2D NMR) studies. The ethyl acetate fraction of alcoholic concentrate (test sample) of flowers of this plant (SBF) was evaluated for its hepatoprotective and inhibition of lipid peroxidation activities to investigate the scientific basis of the traditional uses. The oral administration in varying doses viz., 125 and $250 \mathrm{mg} / \mathrm{kg}$ of aqueous suspension of SBF to rats for 7 days produced significant $(P<$ 0.01 ) hepatoprotective effect comparable to that of standard drug silymarin. The SBF afforded good hepatoprotection against $\mathrm{CCl}_{4}$ induced elevation levels of serum marker enzymes, serum bilirubin and liver weight. The free radical scavenging effects of SBF and flavonol glycoside (SA) were assigned by $\mathrm{Fe}^{2+} /$ ascorbate induction method (in vitro), which revealed the inhibition of lipid peroxidation. The SBF and SA showed prominent anti-lipid peroxidation activity $\left(\mathrm{IC}_{50}\right.$ about $\sim 180 \mathrm{mg} / \mathrm{ml}$ and $11.0 \mathrm{mg} / \mathrm{ml}$ respectively), which was comparable to standard drug curcumin (IC $\mathrm{I}_{50}$ about $\sim 8.25 \mathrm{mg} / \mathrm{ml}$ ). Thus the hepatoprotective activity of SB could be correlated to the free radical scavenging property of the flavonol glycoside.
\end{abstract}

Key words: Sarcostemma brevistigma Wight Syn; Flavonol glycoside; Hepatoprotective activity; Free radical scavenging effect

\section{INTRODUCTION}

Sarcostemma brevistigma Wight Syn (SB); S.acidum Roxb Voight, Asclepias acida Roxb; (Family: Asclepiadaceae) is a leafless trailing jointed shrub which grows throughout India and other tropical regions of the world (Kirtikar and Basu, 1987). Flowers and

${ }^{*}$ Correspondence: MG Sethuraman, Department of Chemistry, Gandhigram Rural Institute, Gandhigram 624 302, Tamil Nadu, India. Tel: +0914512452371; Fax: +04512454466; E-mail: mgsethu@gmail.com, mgsethu@ rediffmail.com leaves of S. brevistigma are used as an antivenom (Selvanayahgam et al., 1994). Preliminary ethnobotanical survey carried out by us revealed the use of aerial parts of this plant for liver disorders in Kolli Hills, Tamil Nadu. Hence the study on phytochemical constituents and hepatoprotective activity of flowers of this plant was undertaken.

\section{MATERIALS AND METHODS}

\section{Plant material}

The Shade-dried flowers of Sarcostemma brevistigma 
Wight Syn (SBF) were collected in January 2002 from Kolli Hills of Tamil Nadu and authenticated by P. Daniel, Botanical Survey of India, Coimbatore, Tamil Nadu. A voucher specimen GUHS-02-12 of the plant has been deposited in the Department of Chemistry at Gandhigram Rural University, Gandhigram.

\section{Extraction, isolation and characterization}

The fresh flowers $(2 \mathrm{~kg})$ were shade dried and extracted with petroleum ether $\left(60-80^{\circ} \mathrm{C}\right)[3.5 \mathrm{l}]$ and $80 \%(\mathrm{v} / \mathrm{v})$ ethyl alcohol [3.5 l] successively in hot condition for $6 \times 6 \mathrm{~h}$ each. The extracts were dried using a rotary evaporator at a temperature not exceeding $55^{\circ} \mathrm{C}$ and the yield were approximately $2.7 \%$ and $5.2 \% \mathrm{w} / \mathrm{w}$ respectively on wet weight basis. The aqueous concentrate of the alcoholic extract was successively extracted with benzene $(4 \times 300 \mathrm{ml})$, diethyl ether $(3 \times 300 \mathrm{ml})$ and ethyl acetate $(4 \times 300 \mathrm{ml})$ and the respective fractions were collected and concentrated in vacuo and the yield were approximately $(10 \mathrm{~g}) 0.5 \%$, (15 g) $0.75 \%$, (20 g) $1.0 \% \mathrm{w} / \mathrm{w}$ respectively.

The ethyl acetate fraction $(20 \mathrm{~g})$ gave yellow solid (SBF) which was non homogenous in TLC and was chromatographed in silica gel (60 - 120 mesh, $400 \mathrm{~g}, 100 \times 5 \mathrm{~cm}$ ) column, using gradient elution with the solvents of increasing polarity. The $100 \%$ ethyl acetate eluent fractions afforded the pale yellow solid (SA), which responded positively for ferric chloride test, gave yellow colouration when fumed with ammonia (characteristic of polyphenolics) and gave violet colouration with Molisch's reagent (characteristic of glycoside) (Kokate, 2003). SA was subjected to acid hydrolysis and the aglycone and sugars were separated and the mobility of these in various solvents was studied (Markham, 1982). $\mathrm{UV},{ }^{1} \mathrm{H} \mathrm{NMR},{ }^{13} \mathrm{C} \mathrm{NMR},{ }^{1} \mathrm{H}-{ }^{1} \mathrm{H}$ COSY, HSQC, HMBC and EI-MS were also recorded for SA.

\section{Hepatoprotective activity}

The ethics committee of Vinayaka Mission's College of Pharmacy, Salem has approved the experimental protocol VM-02-42 used in this study. The $\mathrm{LD}_{50}$ value of SBF was determined in mice by Miller and Tainter method. (Miller and Tainter, 1944). The SBF and silymarin were suspended in $0.5 \%(\mathrm{w} / \mathrm{v})$ gum acacia and used for studying antihepatotoxic activity. Male Wistar rats weighing between 150 - 170 g were fed on commercial diet (Hindustan lever, Bangalore) and water ad libitum during experiments and were divided into five groups, each group consisting of six animals. Hepatoprotective activity of SB was evaluated using $\mathrm{CCl}_{4}$-induced model (Saraf and Dixit, 1991). In view of the fact that the SBF did not produce $50 \%$ mortality even at a dose of 5000 $\mathrm{mg} / \mathrm{kg}$ and the content of flavonoids, which were suspected to be the active principle (Handa, 1986) is only $0.0025 \%$, the two doses viz., 125 and $250 \mathrm{mg} / \mathrm{kg}$ were chosen for SBF. Group I, kept on normal diet, received 0.5\% (w/ v) gum acacia at a dose of $2 \mathrm{ml} / \mathrm{kg}$ and served as control, the group II received $\mathrm{CCl}_{4}(1.25 \mathrm{ml} / \mathrm{kg}$ p.o.), the group III received silymarin, the standard drug (100 mg/kg p.o.), while the groups IV and V received the test drug at a dose of 125 and $250 \mathrm{mg} / \mathrm{kg}$ p.o. respectively daily for seven days.

On the seventh day, the animals were given $\mathrm{CCl}_{4}$ by oral route $30 \mathrm{~min}$ after the administration of silymarin and test samples. After $36 \mathrm{~h}$ of $\mathrm{CCl}_{4}$ administration, blood samples were collected and serum was separated for various biochemical analysis. Biochemical parameters like serum glutamic oxaloacetate transaminase (SGOT) (Reitman and Frankel, 1957), serum glutamic pyruvate transaminase (SGPT) (Reitman and Frankel, 1957), alkaline phophatase (ALP) (Kind and King, 1954), total bilirubin (Mallay and Evelyn, 1937), and gamma glutamate transpeptidase (GGTP) (Szasz, 1969) were analyzed. The liver was examined grossly, weighed and stored in formalin $(10 \% \mathrm{v} / \mathrm{v})$ and was processed for paraffin embedding using the standard microtechnique (Galigher and Kozloff, 
1971). A section of the liver (5 m) stained with alum haemotoxylin and eosin was observed microscopically for histopathological studies. All values were expressed as mean \pm S.E.M. The data were statistically analyzed by one-way ANOVA followed by Dunnett multiple comparison's test. $P$ values $<0.05$ were considered significant.

Determination of lipid peroxidation inhibiting activity (Induction by $\mathrm{FeCl}_{2}$ / ascorbate)

The lipid peroxidation effects of SBF and SA were studied in vitro, (Kimuya et al., 1981) using curcumin as the reference compound. The solution of SBF, SA and curcumin were prepared by dissolving in dimethyl sulfoxide. Protein content was determined (Lowry et al., 1951), using bovine serum albumin as standard. The experiment was repeated for five times. The results were expressed in terms of malonodialdehyde (MDA) formed and the $\mathrm{IC}_{50}$ values were determined by graphical extrapolation as reported earlier (Ghosh, 1971).

\section{RESULTS}

\section{Structure elucidation}

The $100 \%$ ethyl acetate eluent fractions of column chromatography of SBF afforded the pale yellow solid (SA), which responded positively for flavonoid glycoside (m.p $1951^{\circ} \mathrm{C}$, yield $50 \mathrm{mg}, 0.0025 \% \mathrm{w} / \mathrm{w}$ ). It showed intense absorption maxima at $258 \mathrm{~nm}$ (band II) and $357 \mathrm{~nm}$ (band I) indicating a flavonol type skeleton with substitution at $3-\mathrm{OH}$. The ${ }^{1} \mathrm{H}$ NMR, HSQC and HMBC data of SA are tabulated in Table 1.

\section{Hepatoprotective activity}

Table 2 shows that the animals of group II, which received only $\mathrm{CCl}_{4}$ were found to develop significant hepatic damage which was observed from elevated levels of SGPT, SGOT, ALP, total bilirubin, GGTP and liver weight as compared to group I normal animals. SBF treatment at a dose of $250 \mathrm{mg} / \mathrm{kg}$, p.o could prevent the increase in the levels of various marker enzymes after $\mathrm{CCl}_{4}$ administration.

Histological section of control animals (Group I)

Table 1. ${ }^{1} \mathrm{H}$ NMR, HSQC and HMBC data of SA

\begin{tabular}{ccl}
\hline $\begin{array}{c}\text { Proton signal } \\
\delta \mathrm{H}(\mathrm{ppm})\end{array}$ & $\begin{array}{c}\text { Correlated Carbon } \\
\text { signal in HSQC dppm }\end{array}$ & \multicolumn{1}{c}{$\begin{array}{c}\text { Correlated carbon signal in HMBC } \\
\delta(\mathrm{ppm})\end{array}$} \\
\hline $7.59 \mathrm{H}-2 \mathrm{a} / 6 \mathrm{a}$ & 115.1 and 121.6 & $115.1(\mathrm{C}-2 \mathrm{a}), 121.6(\mathrm{C}-6 \mathrm{a}), 120.9(\mathrm{C}-5 \mathrm{a}), 122.0(\mathrm{C}-1 \mathrm{a})$, \\
& & $156.4(\mathrm{C}-2), 144.8(\mathrm{C}-3 \mathrm{a})$ \\
$7.45 \mathrm{H}-2 \mathrm{f} / 6 \mathrm{f}$ & 131.0 & $131.0(\mathrm{C}-2 \mathrm{f} / 6 \mathrm{f}), 127.6(\mathrm{C}-1 \mathrm{f}), 116.2(\mathrm{C}-3 \mathrm{f} / 5 \mathrm{f})$ \\
$7.36 \mathrm{H}-\beta$ & 144.7 & $144.7(\mathrm{C}-\beta), 116.0(\mathrm{C}-\alpha), 127.6(\mathrm{C}-1 \mathrm{f})$ \\
$6.80 \mathrm{H}-3 \mathrm{f} / 5 \mathrm{f}$ & 116.2 & $116.2(\mathrm{C}-3 \mathrm{f} / 5 \mathrm{f}), 131.0(\mathrm{C}-2 \mathrm{f} / 6 \mathrm{f}), 159.9(\mathrm{C}-4 \mathrm{f})$ \\
$6.43 \mathrm{H}-8$ & 93.7 & $93.7(\mathrm{C}-8), 156.4(\mathrm{C}-9), 162.5(\mathrm{C}-7)$ \\
$6.32 \mathrm{H}-\alpha$ & 116.0 & $116.0(\mathrm{C}-\mathrm{\alpha}), 144.7(\mathrm{C}-\beta), 166.1(\mathrm{C}=\mathrm{O})$ of coumaroyl \\
$6.22 \mathrm{H}-6$ & 98.7 & $98.7(\mathrm{C}-6), 162.5(\mathrm{C}-7), 161.2(\mathrm{C}-5)$ \\
$5.80 \mathrm{H}-1 \mathrm{~b}$ & 101.7 & $101.7(\mathrm{C}-1 \mathrm{~b}), 133.2(\mathrm{C}-3), 73.4(\mathrm{C}-2 \mathrm{~b})$ \\
$5.40 \mathrm{H}-1 \mathrm{c}$ & 101.8 & $101.8(\mathrm{C}-1 \mathrm{~b}), 162.5(\mathrm{C}-7), 77.8(\mathrm{C}-2 \mathrm{c})$ \\
$5.39 \mathrm{H}-2 \mathrm{e}$ & 121.1 & $121.1(\mathrm{C}-2 \mathrm{e}), 29.0(\mathrm{C}-1 \mathrm{e}), 129.4(\mathrm{C}-3 \mathrm{e})$ \\
$4.90 \mathrm{H}-1 \mathrm{~d}$ & 102.1 & $102.1(\mathrm{C}-1 \mathrm{~d}), 77.8(\mathrm{C}-2 \mathrm{c}) 69.5(\mathrm{C}-2 \mathrm{~d})$ \\
$4.60 \mathrm{H}-4 \mathrm{c}$ & 71.2 & $166.1(\mathrm{C}=\mathrm{O})$ of coumaroyl, 71.2(C-4c) \\
$4.0-3.3$ & $60-80$ & $60-80(\mathrm{sugar}$ carbon) \\
$3.20 \mathrm{H}-1 \mathrm{e}$ & 29.0 & $29.0(\mathrm{C}-1 \mathrm{e}), 121.1(\mathrm{C}-2 \mathrm{e}), 120.9(\mathrm{C}-5 \mathrm{a})$ \\
$1.50 \mathrm{H}-4 \mathrm{e}, \mathrm{H}-5 \mathrm{e}$ & 15.1 and 25.0 & $15.1(\mathrm{C}-4 \mathrm{e}), 25.0(\mathrm{C}-5 \mathrm{e}), 129.4(\mathrm{C}-3 \mathrm{e})$ \\
$1.20 \mathrm{H}-6 \mathrm{~d}$ & 20.1 & $20.1(\mathrm{C}-6 \mathrm{~d}), 67.9(\mathrm{C}-5 \mathrm{~d})$ \\
\hline
\end{tabular}


Table 2. Effects of SBF on levels of biochemical parameters and liver weight variation in $\mathrm{CCl}_{4}$ treated rats

\begin{tabular}{cccccccc}
\hline $\begin{array}{c}\text { Design of } \\
\text { treatment }\end{array}$ & $\begin{array}{c}\text { Dose } \\
(\mathrm{mg} / \mathrm{kg})\end{array}$ & $\begin{array}{c}\text { SGPT } \\
\mathrm{U} / 1\end{array}$ & $\begin{array}{c}\text { SGOT } \\
\mathrm{U} / 1\end{array}$ & $\begin{array}{c}\text { ALP } \\
\mathrm{U} / 1\end{array}$ & $\begin{array}{c}\text { Total Bilirubin } \\
(\mathrm{mg} \%)\end{array}$ & $\begin{array}{c}\text { GGTP } \\
\mathrm{U} / 1\end{array}$ & $\begin{array}{c}\text { Liverwt } / 100 \mathrm{~g} \\
\text { body wt }(\mathrm{g})\end{array}$ \\
\hline Group Icontrol & $2 \mathrm{ml} / \mathrm{kg}$ & $131.50+0.80$ & $45.30+0.80$ & $195.60+10.60$ & $0.70+0.03$ & $123.00+4.10$ & $4.10 \pm 0.01$ \\
Group II CCl & $1.25 \mathrm{ml} / \mathrm{kg}$ & $217.30+4.50^{\mathrm{a}}$ & $341.00+3.80^{\mathrm{a}}$ & $388.60+19.20^{\mathrm{a}}$ & $1.20+0.07^{\mathrm{a}}$ & $257.30+5.30^{\mathrm{a}}$ & $6.50 \pm 0.28^{\mathrm{a}}$ \\
Group III silymarin & 100 & $138.0+2.10^{\mathrm{a}}$ & $81.30+9.10^{\mathrm{a}}$ & $218.60+5.40^{\mathrm{a}}$ & $0.80+0.07^{\mathrm{a}}$ & $124.60+5.20^{\mathrm{a}}$ & $4.10 \pm 0.26$ \\
Group IV SBF & 125 & $142.10+1.80^{\mathrm{a}}$ & $90.10+3.40^{\mathrm{a}}$ & $324.00+4.90^{\mathrm{a}}$ & $0.94+0.03^{\mathrm{a}}$ & $130.30+2.40^{\mathrm{a}}$ & $4.60+0.18^{\mathrm{a}}$ \\
Group V SBF & 250 & $132.30+1.90$ & $76.00+1.10^{\mathrm{a}}$ & $222.60+5.30^{\mathrm{a}}$ & $0.90+0.01^{\mathrm{a}}$ & $126.00+2.40^{\mathrm{a}}$ & $4.10 \pm 0.10$ \\
\hline
\end{tabular}

$\mathrm{n}=6$ animals in each group; ${ }^{a} P<0.01$; when compared to $\mathrm{CCl}_{4}$. Data were analyzed by one-way ANOVA followed Dunnett multiple comparison's test. Values are expressed as mean \pm S.E.M.

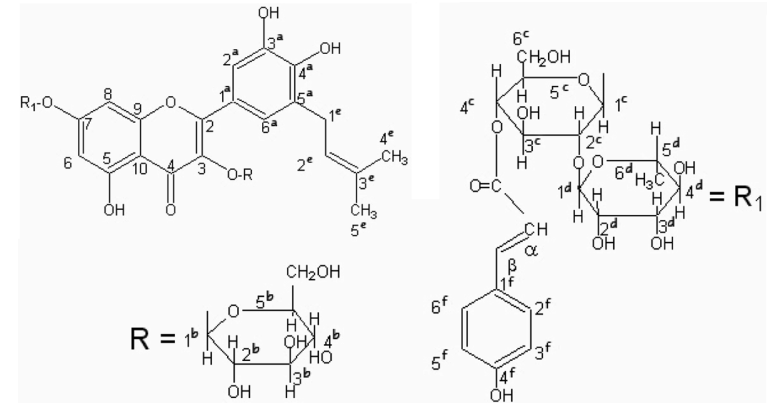

Fig. 1. Structure of SA.

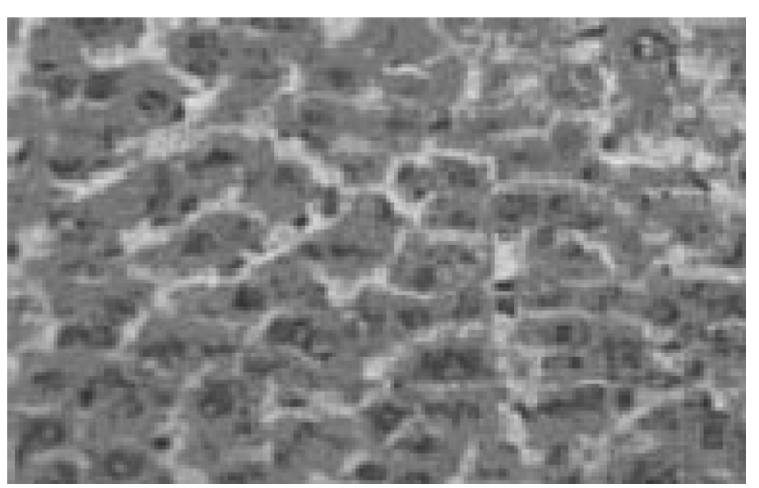

Fig. 2. Biopsy study of the liver of normal group.

showed normal hepatic cells with well-preserved cytoplasm, prominent nucleus and nucleolus and conspicuous central vein (Fig. 2). Histological section of Group II animals showed high degree of damage characterized by cell vacuolation, pyknotic and degenerated nuclei and damage to wall of capillaries (Fig. 3). Histopathological profile of the Group III animals showed the recovery against the $\mathrm{CCl}_{4}$ induced damage as compared to control (Fig. 4). The histological section of the Group IV

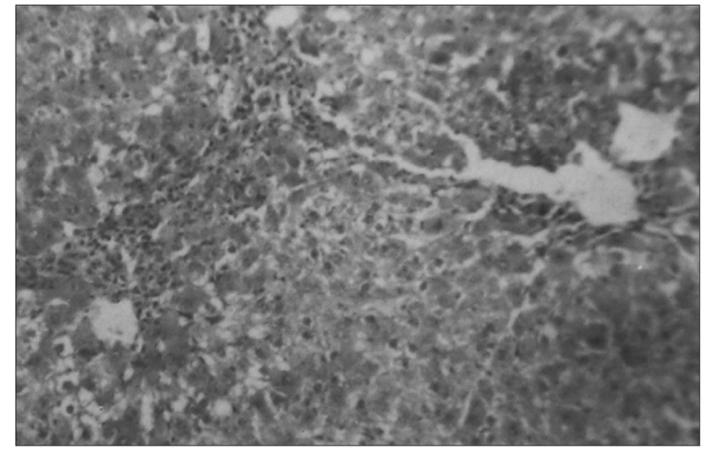

Fig. 3. Biopsy study of the $\mathrm{CCl}_{4}$ intoxicated liver.

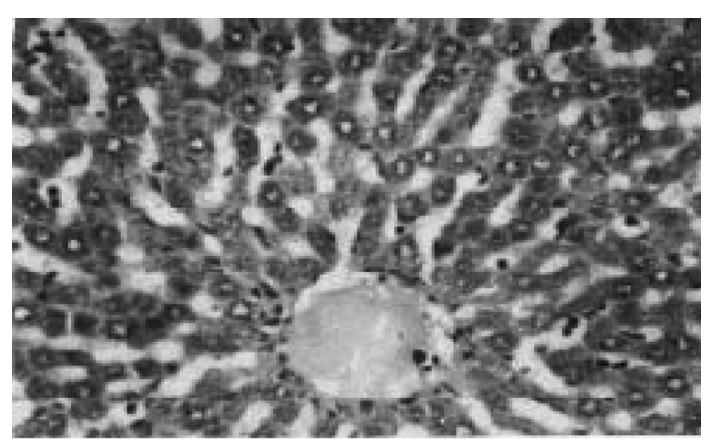

Fig. 4. Biopsy study of the $\mathrm{CCl}_{4}$ intoxicated liver treated with the standard drug silymarin.

animals showed that nuclei were not clear as in normal hepatocytes but when compared to the $\mathrm{CCl}_{4}$ damage ones, the hepatocytes with normal nucleus were more. Endothelium was disrupted at places but in lesser numbers than $\mathrm{CCl}_{4}$ intoxicated rats. Hepatic cells adjoining the interlobular vein showed atrophy. Pyknotic nucleus and vacuolation in cytoplasm were observed to be low. There seemed to be a satisfactory recovery (Fig. 5). 


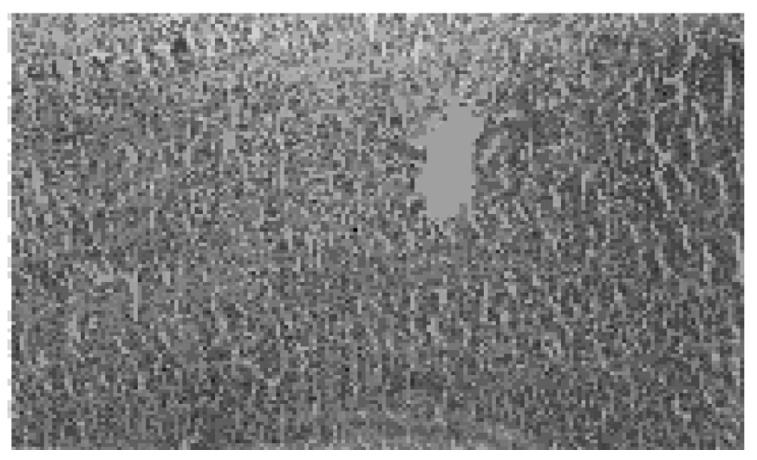

Fig. 5. Biopsy study of the $\mathrm{CCl}_{4}$ intoxicated liver treated with ethyl acetate concentrate of $S B$.

\section{Lipid peroxidation activity}

The results of antioxidant studies carried out using $\mathrm{Fe}^{2+}$ /ascorbate induction method clearly reveals that $\mathrm{SBF}$ at $200 \mathrm{mg} / \mathrm{ml}$ and SA at $20 \mathrm{mg} / \mathrm{ml}$ act as a radical scavenger and inhibits lipid perioxidation (53.42\% and $67.69 \%$ respectively) comparable to curcumin at $20 \mathrm{mg} / \mathrm{ml}(68.53 \%)$, the standard drug used. The SBF and SA showed prominent anti-lipid peroxidation activity $\left(\mathrm{IC}_{50}\right.$ about $180 \mu \mathrm{g} / \mathrm{ml}$ and 11.0 $\mu \mathrm{g} / \mathrm{ml}$ respectively), which were comparable to standard drug curcumin ( $\mathrm{IC}_{50}$ about $\left.8.25 \mu \mathrm{g} / \mathrm{ml}\right)$.

\section{DISCUSSION}

SA (m.p $1951^{\circ} \mathrm{C}$, yield $50 \mathrm{mg}, 0.0025 \%$ ) showed intense absorption maxima at $258 \mathrm{~nm}$ (band II) and $357 \mathrm{~nm}$ (band I) indicating a flavonol type skeleton with substitution at $3-\mathrm{OH}$. A bathochromic shift of $+51 \mathrm{~nm}$ of band I on addition of $\mathrm{NaOMe}$ showed the presence of hydroxyl group at C-4a. The characteristic bathochromic shift was not observed on band II on the addition of $\mathrm{NaOAc}$, which suggested the non-existence of free hydroxyl group at C-7. Further no correlation of H-6 proton (6.22 ppm) or H-8proton (6.43 ppm) with C-7 was observed in ${ }^{1} \mathrm{H}-{ }^{1} \mathrm{H}$ COSY spectrum of SA and it was taken as the further evidence for the presence of substitution at C-7. A bathochromic shift of band I on addition of $\mathrm{NaOAc} / \mathrm{H}_{3} \mathrm{BO}_{3}$ (+22 nm) confirmed the presence of ortho-dihydroxyl group in ring $\mathrm{B}$. Band I underwent a bathochromic shift of $+39 \mathrm{~nm}$ on the addition of $\mathrm{AlCl}_{3} / \mathrm{HCl}$ which indicated the presence of $5-\mathrm{OH}$ in SA.

In ${ }^{1} \mathrm{H}$ NMR a downfield signal at $12.65 \mathrm{ppm}$ showed the presence of a chelatogenic $\mathrm{OH}$ at C-5. Glycosidic nature of SA was ascertained by colour reactions (Kokate, 2003) and hydrolytic studies. The Rf values in various solvent systems were supportive of a trioside. He estimation of sugars revealed the presence of glucose and rhamnose in the ratio of 2:1(Markham, 1982).

The ${ }^{1} \mathrm{H}$ NMR and ${ }^{13} \mathrm{C}$ NMR also suggested the presence of two glucopyranosyl moieties with $\beta$ configuration and one rhamnopyranosyl residue with $\alpha$ configuration. The signals displayed at 4.9 ppm $\left({ }^{1} \mathrm{H}, \mathrm{d}, \mathrm{J}=2 \mathrm{~Hz}, \mathrm{H}-1 \mathrm{~d}\right)$ and ppm $\left({ }^{1} \mathrm{H}, \mathrm{d}, \mathrm{J}=6\right.$ $\mathrm{Hz}, \mathrm{H}-6 \mathrm{~d})$ in ${ }^{1} \mathrm{H}$ NMR and signal at $61.1 \mathrm{ppm}$ in ${ }^{13} \mathrm{C}$ NMR revealed the neohesperidoside nature of the glycoside (Mabry et al., 1970).

After acid hydrolysis, a mixture of aglycone and coumaric acid was obtained. From the studies of ${ }^{1} \mathrm{H}$ NMR, ${ }^{13} \mathrm{C}$ NMR (Matsuda, et al., 2002), ${ }^{1} \mathrm{H}-{ }^{1} \mathrm{H}$ COSY, HSQC and HMBC (Table 1), the presence of coumaroyl group was evident. A large coupling constant of $(\mathrm{J}=15.8 \mathrm{~Hz})$ observed between the olefinic protons (H- and $\mathrm{H}-$ ) in acyl moiety of SA confirmed the trans configuration of $\mathrm{H}$ - and $\mathrm{H}$ (Chaudhuri and Thakur, 1986). The fragment lines of $\mathrm{m} / \mathrm{z} 164$ and 147 implied the presence of pcoumaroyl moiety (Mizuno et al., 1987).

The anomeric proton at $\mathrm{d} 5.4 \mathrm{ppm}$ (glucose $\mathrm{H}-1 \mathrm{c}$ ) was correlated with C-7 (d $162.5 \mathrm{ppm}$ ) and the anomeric proton at $\mathrm{d} 4.9 \mathrm{ppm}$ (rhamnose $\mathrm{H}-1 \mathrm{~d}$ ) was correlated with C-2c (d 77.8 ppm) in HMBC spectrum, which revealed the attachment positions of neohesperidoside at C-7 (Table 1). Further correlation observed between the anomeric proton signal at d 5.8 ppm (glucose $\mathrm{H}-1 \mathrm{~b}$ ) and $\mathrm{d} 133.2$ ppm (C-3 signal) in HMBC spectrum revealed the attachment of glucose at C-3 (Table 1).

The attachment of coumaroyl group with the glucose moiety of neohesperidoside was confirmed by the correlation of H-4c signal (4.6 ppm) of glucose with carbonyl carbon signal (166.0 ppm) 
of coumaroyl group, in the HMBC spectrum (Table 1). The presence of prenyl group was established by ${ }^{1} \mathrm{H}$ and ${ }^{13} \mathrm{C}$ NMR spectroscopic analysis whose assignments were facilitated by HSQC and HMBC experiments and were in agreement with values reported in the literature for the presence of prenyl group (Tahara et al., 1994). This was further evidenced by the appearance of mass spectral line of $m / z 69$ in EI-MS spectrum of SA.

Since ${ }^{1} \mathrm{H}$ NMR spectrum revealed the presence of only H-2a, 6a protons and further UV studies had already confirmed the presence of o-diOH groups at C-3a, 4a, the position of attachment of prenyl group could be only at C-5a. The EI-MS of SA exhibited molecular ion peak at $\mathrm{m} / \mathrm{z} 369(\mathrm{M}-1+2)$, with diagnostic retro-Diels-Alder cleavage of ring $C$ at $m / z$ 153 and 205 supporting the presence of two hydroxyl in ring $\mathrm{A}$ and two hydroxyl and one prenyl in ring $\mathrm{B}$.

Thus on the basis of $\mathrm{UV},{ }^{1} \mathrm{HNMR},{ }^{13} \mathrm{CNMR},{ }^{1} \mathrm{H}^{-1} \mathrm{H}$ COSY, HSQC, HMBC and EI-MS, SA has been characterized as quercetin 5a prenyl, 3-O- glucosyl, 7$\mathrm{O}-(4 \mathrm{c}-\mathrm{p}$-coumaroyl) neohesperidoside.

The hepatotoxicity induced by $\mathrm{CCl}_{4}$ is due to its metabolites viz., trichoromethyl $\left(\mathrm{CCl}_{3}{ }^{2}\right)$ and trichloromethyl peroxy $\left(\mathrm{CCl}_{3} \mathrm{O}_{2}^{2}\right)$, radicals that bind to lipoprotein and lead to peroxidation of lipids of endoplasmic reticulum (Recknagael, 1967). The ability of a hepatoprotective drug to reduce the injurious effects or to preserve the normal hepatic physiological mechanisms, which have been disturbed by a hepatotoxin, is the index of its protective effects. Protection of hepatic damage caused by $\mathrm{CCl}_{4}$ administration observed by changes in the marker enzymes such as SGPT, SGOT, ALP, total bilirubin and GGTP in normal, toxin treated, standard drug (silymarin) treated and SBF treated (both $125 \mathrm{mg} / \mathrm{kg}$ and $250 \mathrm{mg} / \mathrm{kg}$ ) groups. The disturbance in the transport function of the hepatocytes as a result of hepatic damage causes the leakage of enzymes from cells due to altered permeability of membrane (Zimmerman and Seeff, 1970). This results in decreased levels of SGOT and SGPT in the hepatic cells and a raise in their serum level. From the Table 2, it was clear that SBF showed greater protection at a dose of 250 $\mathrm{mg} / \mathrm{kg}$ and the values are comparable to those of silymarin, the standard drug used. The weight of the liver remained normal in the cases of silymarin and SBF treated groups. A significant protection $(P<0.01)$ in liver weights supports this finding.

The histopathological studies offer direct evidences of efficacy of SBF as hepatoprotective agent. The SBF treated group showed good recovery of the hepatocytes. The liver sections showed almost disappearance of fatty deposit and necrosis, comparable to the standard drug silymarin. The lesions developed on treatment with $\mathrm{CCl}_{4}$ (Fig. 3), were found to be normalized with near normal histoarchitecture of liver cells, in standard drug (Fig. 4) and SBF treated animals (Fig. 5).

The SBF and SA showed prominent anti lipid per oxidation activity $\left(\mathrm{IC}_{50}\right.$ about in $180.0 \mu \mathrm{g} / \mathrm{ml}$ and $11.0 \mu \mathrm{g} / \mathrm{ml}$ respectively), which were comparable to standard drug curcumin $\left(\mathrm{IC}_{50}\right.$ about $\left.8.25 \mu \mathrm{g} / \mathrm{ml}\right)$. Many plants exhibit efficient antioxidant properties owing to their phenolic constituents. Most of the tannins and flavonoids are phenolic compounds and are responsible for antioxidant properties of many plants (Larson, 1998). The role of free radicals in many disease conditions has been well established. Several biochemical reactions in our body generate reactive oxygen species and these are capable of damaging crucial bio-molecules. If they are not effectively scavenged by cellular constituents, they lead to disease conditions. (Halliwell and Gutteridge, 1985). Drugs that act against free radical or scavenge it may be very useful in various free radical induced debilitating diseases such cancer or carcinoma, diabetes, hypertention, liver disorders and tumour. Thus the hepatoprotective activity of SB could be correlated to the free radical scavenging property of the flavonol glycoside.

\section{CONCLUSION}

The study clearly proves that the radical scavenging 
property of SA (Quercetin 5a prenyl, 3-O-glucosyl, 7-O-(4c-p-coumaroyl) neohesperidoside) is responsible for the observed hepatoprotective activity of SBF. It is a known fact that flavonoids have a high safety margin and are free from side effects such as ulcerogenicity (Alvaraz et al, 1999). The results of the present study advocate the full exploitation of S. brevistigma as a hepatoprotective agent in the management of liver disorders after proper clinical trials.

\section{ACKNOWLEDGEMENTS}

The authors are thankful to Dr. B. Jayakar, Dr. B. Rajkapoor, Sri Vinayaka Misson's College of Pharmacy, Salem and the authorities of the Gandhigram Rural University, Gandhigram for their help to carry out present research work.

\section{REFERENCES}

Alvaraz A, Pomar F, Sevilla MA, Montereo MJ. (1999) Gastric antisecretory and antiulcer activities of an ethanolic extract of Bidens pilosa L. Var radiate Schult. Bip. J. Ethnopharmacol. 67, 333-340.

Chaudhuri PK, Thakur RS. (1986) An acylated flavone apigenin 7-O- $\beta$-D (4" cis-p-coumaroyl) glucoside from Ehinops echinatus. Phytochemistry 25, 1770-1771.

Galigher AE, Kozloff EN. (1971) Essential Practical Microtechnique. Lea and Febiger, Philadelphia 2, 197-210.

Ghosh MN. (1971) Fundamentals of Experimental Pharmacology. Scientific Book Agency, Calcutta 112.

Handa SS, Anupam Sharma Chakrabarthi KK. (1986) Natural products and plants as liver protecting drugs. Fitoterapia 57, 307-351.

Halliwell B, Gutteridge JMC. (1985) In: Free Radicals, ageing and Disease, Free radicals in Biology and Medicine. Clarendron Press, Oxford 2, 279-315.

Kimuya Y, Kubo M, Tani T, Arichi S, Okuda H. (1981) Studies on Scutellariae radix. IV. Effects on lipid peroxidation in rat liver. Chem. Pharm. Bull. 29, 26102617.

Kind PR, King EJ. (1954) Estimation of plasma phosphatase by determination of hydrolysed phenol with amino-antipyrine. J. Clin. Pathol. 7, 322-326.

Kirtikar KR, Basu BD. (1987) Indian Medicinal Plants,
Lalit Mohan Basu, (Ed.). International Book Publishers, Dehradun 3, 1621-1622.

Kokate CK. (2003) Practical Pharmacognosy. Nirali Prakashan, India 4, 150-156.

Larson RA. (1988) The Antioxidants of Higher Plants. Phytochem. 27, 969-978.

Lowry OH, Rosenbrough NT, Farr AL, Randall RJ. (1951) Protein measurement with the folin phenol reagent. J. Biol. Chem. 193, 265-275.

Mabry TJ, Markham KR, Thomas MB. (1970) The Systematic Identification of Flavonoids. Springerverlag, New York 269.

Mallay HT, Evelyn KA. (1937) Estimation of serum bilirubin level with the photoelectric colorimeter. J. Biol. Chem. 119, 481-484.

Markham KR, (1982) Techniques of Flavonoid Identification. Academic Press, London 53-54.

Matsuda H, Nishida N, Yoshikawa M. (2002) Antidiabetic principles of natural medicines. V. Aldose reductase inhibitors from Myrcia multiflora DC. (2): Structures of myrciacitrins III, IV, and V. Chem. Pharm. Bull. 50, 429-431.

Miller LC, Tainter ML. (1944) Estimation of ED50 and its errors by means of logarithmic probit graph paper. Proc. Soc. Exptl Biol Med. 57, 261-264.

Mizuno M, Kato M, Iinuma M, Tanaka T, Kimura A, Ohashi H, Sakai H. (1987) Acylated luteolin glycosides from Salix gilgiana. Phytochemistry 26, 2418-2420.

Recknagael R. (1967) Carbon tetrarchloride hepatotoxicity. Pharmacol. Rev. 19, 145-196.

Reitman S, Frankel AS. (1957) A colorimetric method for determination of serum glutamate oxaloaectate and glutamic pyruvate transaminase. Am. J. Clin. Pathol. 28, 56-63.

Saraf S, Dixit VK. (1991) Hepatoprotective activity of Tridax procumbens. Part II. Fitoterapia 62, 534-536.

Selvanayahgam ZE, Gnanevendhan SG, Balakrishna K, Rao RB. (1994) Antisnake venom botanicals from ethnomedicine. J. Herbs Spices Med. Plants 2, 45-100.

Szasz G. (1969). A kinetic photometric method for serum gamma-glutamyl transpeptidase. Clin. Chem. 15, 124-36.

Tahara S, Katagiri Y, Ingham JL, Mizutani J. (1994) Prenylated flavonoids in the roots of yellow lupin. Phytochemistry 36, 1261-1271.

Zimmerman HJ, Seeff LB. (1970) Enzymes in hepatic disease, In: Diagnostic Enzymology, Goodly E.L. (Ed.). Lea and Febiger, Philadelphia. 